\title{
The (Post)human Condition and Decoloniality: Rethinking and Doing Curriculum
}

\section{Lesley Le Grange \\ ORCID iD: https://orcid.org/0000-0002-7096-3609}

\begin{abstract}
Contemporary society is faced with multiple and complex challenges. These challenges include growing inequality in the world, unprecedented levels of environmental problems and rapid advances in new technologies. These challenges present both opportunities and threats. Rosi Braidotti describes this state of affairs as a (post)human condition characterized by a predicament. The (post)human predicament relates to how one adopts the positive dimension of the (post)human condition by embracing all of life and its interconnectedness, and at the same time to how one resists the potential negative effects of advanced technologies. For decolonial scholars the complex challenges mentioned are the consequence of a colonial matrix of power, which is the legacy of colonialism. The (post)human condition and decolonial turn raise critical existential as well as educational questions such as: How should we live? What is now the unit of reference for the human? How should we learn? What knowledge is of most worth? Whose knowledge is of most worth? In this article I explore potential resonances between (post)humanism and decoloniality and propose ubuntu-currere as a concept for reimagining curriculum in the post-Anthropocene.
\end{abstract}

Keywords: curriculum, Curriculum Studies, decoloniality, (post)humanism, ubuntu-currere

\section{Background and Introduction}

Global society is faced with a myriad set of complex problems. There is growing inequality in the world, the planet is on the brink of ecological 


\section{Lesley le Grange}

disaster, new technologies producing both benefits and threats are advancing at a rapid rate, and new health risks such as the COVID-19 pandemic are wreaking havoc across the globe. South Africa, as a microcosm of the world, is witness to these same problems. In particular, the country faces the effects of anthropogenic processes in a recent period of human history and a new geological epoch, which scientists have called the Anthropocene ${ }^{1}$ (Le Grange 2019a). However, Morton (2013:5) suggests that the Anthropocene is 'a strange term' because in this new epoch 'non-humans make decisive contact with humans'. One reason for this is that human lives have increasingly become entangled with advanced technologies, as depicted in Haraway's (2006) persuasive, A Cyborg Manifesto ${ }^{2}$. For her, A Cyborg Manifesto means that the secure boundaries between humans and animals as well as between humans and machines has already collapsed. This development is indicative of what might be termed a late Anthropocene or the beginnings of a postAnthropocene.

The current planetary/societal condition is a multifaceted crisis that provokes critical questions, both existential and those related to education. The perennial existential question of how we might live in troubled times comes to the fore. Another existential question concerns how we ought to live in the present with an awareness of the possibility of a planet-without-us. Moreover, the very notion of the human has come under scrutiny and is captured in the question: What now is the unit of reference for human? Education questions (old and new ones) have also arisen, such as What knowledge is of most worth? (Is this question even still a relevant one?) Whose knowledge is of most worth? Is knowledge enough? How might we learn in the post-Anthropocene?

The challenges mentioned have a bearing on education and are also imbricated with education. For example, inequalities in education systems such as South Africa's reflect the inequalities of the broader society. Moreover,

${ }^{1}$ Haraway (2015) argues that anthropogenic processes go much further back than the time period designated Anthropocene by Crutzen and Stoermer (2000). She argues that it goes back to the invention of agriculture, a time period she names Plantationocene. Moreover, she terms the coextensiveness between past, present, and to come (Plantationocene, Anthropocene, and Capitalocene) as Chthulucene.

2 The first iteration of 'A Cyborg Manifesto' was published by Haraway in the Socialist Review in 1985. 
Bowles and Gintis (1976) taught us that schools in capitalist societies such as the United States of America (and South Africa) function to reproduce the dominant values and class structure of that society. Others have argued that schools can be sites of transformation and that languages of critique need to be augmented by languages of possibility (Giroux 1988) and languages of probability (Deever 1996). In the South African context, Le Grange, Reddy and Beets (2012) show that despite efforts by the government to fund schools in poor areas more favourably through its national quintile system, the public schooling system in South Africa remains grossly unequal because of the marketisation of public schooling that began in the late 1980s. With respect to higher education, participation rates are much lower for African and coloured students than for white students. For example, in 2018 participation rates for African, coloured, Indian and white students were, respectively, 19\%, 15\%, $46 \%$, and 55\% (Council on Higher Education (CHE) 2020). Furthermore, the recent COVID-19 pandemic has laid bare inequalities in higher education in terms of the digital-divide in the country (Du Preez \& Le Grange 2020). But inequalities are deeper than this, as the decolonial moment spurred by the \#RhodesMustFall ${ }^{3}$ and \#FeesMustFall ${ }^{4}$ campaigns, has forcibly reminded us. I refer here to the epistemic violence inflicted on black students and staff by a higher education system whose administrative and curricular organization have been based on Western models to the exclusion of other possibilities. The upshot of this has been a call for decolonising of the university curriculum in South Africa (Le Grange 2016) and for decolonising schools (Christie 2020). When it comes to environmental destruction, formal education has also been implicated. Orr (1992) reminds us that those who are inflicting harm on the planet are not people who have little or no formal education, nor those who are poor, but, instead, those armed with university qualifications. The carbon footprint of the poor person with little formal education is certainly smaller than that of the person who holds a university degree. Orr (1992) pointed out

3 \#RhodesMustFall was a protest campaign at the University of Cape Town where students demanded the removal of the statue of British imperialist Cecil John Rhodes. The statue was symbolic of the cognitive colonisation that remained the order of the day at UCT.

${ }^{4}$ \#FeesMustFall was a nationwide campaign during which students demanded free higher education for poor students but, more broadly, protested against the influence of neoliberal capitalism on the public higher education institution. 


\section{Lesley le Grange}

that formal education teaches students the lesson of hypocrisy - it is good enough to learn about environmental problems without needing to do anything about them. However, many continue to believe that education should and could play a productive role in arresting further environmental destruction. The existence of disciplines such as environmental education and sustainability education bears testimony to this.

In relation to health risks, we have seen the impact of the global COVID-19 pandemic on education as evidenced by the closure of schools and higher education institutions during lockdown periods and, in South Africa, also during certain levels of the government's risk adjusted approach. But the COVID-19 pandemic has also seen some schools and many residential universities pivot from face-to-face contact teaching/learning to what has popularly been called online teaching/learning although experts have suggested emergency remote teaching/learning as a more apposite term (Hodges et al. 2020). This development has the potential to open up new pathways for learning but has also laid bare sharp inequalities in South Africa when viewed from the perspective of the digital divide. Moreover, there is a darker trajectory where platform pedagogy (my term for emergency remote teaching/ learning that uses learning management systems) morphs into platform capitalism. This will occur when for-profit intermediaries such as platform-based businesses become involved in the delivery of higher education, radically changing institutions such as universities and resulting in the casualisation of labour and deprofessionalisation of academics (see Le Grange 2020).

Needless to say, the challenges discussed are interwoven in complex ways. In the brief discussion of the COVID-19 pandemic, lines of connection between the pandemic, education, technology (emergency remote teaching), inequality (digital divide), economy (platform-capitalism) and labour are evident. And many more connections could proliferate. For example, McKinley (2020) argues that the presence of ever-more-virulent viruses such as the one causing COVID-19 is the result of bad agricultural practices and land use linked to industrial capitalism. He argues that the industrial model of agriculture is based on maximizing profits irrespective of what the consequences are for humans, society, and the environment. The potential links, both conceptual and actual/perceived, that could be generated between/among the challenges discussed cannot be captured fully (or at least not in this genre of presentation). But the point is sufficiently made that there 
are multiple and complex connections between and among the challenges mentioned.

Some scholars have argued that the crises mentioned (and many more) are part of a broader problem - the 'crisis of humanism' (Levinas 1987). European enlightenment produced the ideal conception of human that served as the basis for declaring some humans less than human and also separated humans from the more/other-than-human world. Critical responses to humanism gave rise to anti-humanist philosophies and, more recently, to discourses on the (post)human. (Post)human(ist) theories have developed in Western scholarship (of the Global North) and although there is a growing interest in (post)humanism among South African scholars of higher education, it has not penetrated conversations on curriculum significantly. ${ }^{5}$ Other scholars have laid much of the blame for the mentioned crises at the door of European colonisation and new forms of colonisation present in an era of globalisation. Scholarly responses to the effects of colonisation on the individual, society, and environment gave rise to postcolonial and decolonial discourses. Whereas postcolonial discourses have been either produced by scholars located in the Global North or by those who have given epistemic privilege to the Western scholars, decolonial discourses have been predominantly produced by scholars located in the Global South. Grosfuguel (2011) argues that the South Asian Subaltern Studies Group's critique of Eurocentrism was weakened by giving epistemic privilege to Foucault and Gramsci. He makes an important distinction between studies about the subaltern and studies with and from the perspective of the subaltern. Although decolonial scholarship has a long history in Africa and elsewhere, in South Africa its migration into curriculum conversations has been recent, mainly in the wake of the student protest of 2015 and 2016 and the calls by students for the decolonisation of the university curriculum.

My aim in this article is to explore points of resonance and dissonance between (post)humanism and decoloniality so as to open up ways of reimagining curriculum in the post-Anthropocene through invoking the African notion of ubuntu. In doing so, I divide the rest of the article into the following sections: The (post)human (condition); decolonisation and decoloniality;

${ }^{5}$ Du Preez (2018), Murris (2016) and Postma (2016) are examples of scholarly work produced in South Africa that has brought (post)human discourses to bear on matters of curriculum. 
(post)humanism and decoloniality in conversation; ubuntu-currere; some parting thoughts.

\section{The (Post)human Condition and Curriculum}

Braidotti (2013) argues that the (post)human is a condition that marks a qualitative shift in our thinking about what the unit of reference is for the human. The impetus for this shift is a growing awareness of how human lives are imbricated with other inhabitants of the planet and because of the human's entanglement with advanced technologies. For her, this condition is characterised by what she terms a 'post-human predicament' (Braidotti 2013:11). The (post)human predicament relates on the one hand to a historical moment in which global society finds itself, where the human has become a geological force capable of affecting all life on Planet Earth, giving rise to the Anthropocene. And it is in the Anthropocene that we now contemplate what it might mean to live in the post-Anthropocene. On the other hand, the predicament relates to the fact that advanced technologies produced by humans might have capabilities of destroying all life on the planet. In other words, the predicament relates to how one adopts the positive dimension of the (post)human condition by embracing all of life and its interconnectedness, and, at the same time, how one resists the potential negative effects of advanced technologies (robotics, drones, artificial intelligence, biological warfare, commodification of the human body, and ecophages ${ }^{6}$ ) without being technophobic.

I agree with Braidotti that the (post)human is a condition and contend that intellectual work variously labelled new materialism, speculative realism, non-representative theory, etc. are efforts by communities of scholars to work out 'academic theories' associated with this condition. I shall briefly describe three such 'academic theories' and suggest what makes them (post)human. New materialism is an interdisciplinary field comprised of feminist scholars from a range of disciplines in the natural and social sciences. New materialism brings under erasure the privileging of subjectivity and representation and, according to Braidotti (2012), replaces textual and other deconstruction with an ontology of modulated presence. Scholars of this field find inspiration in thinking with Deleuze, and, in particular, the later Deleuze who collaborated

${ }^{6}$ Ecophages are self-reproducing molecular substances that nanotechnology can potentially produce and that will have the capability of gobbling up things. 
with Guattari in placing the human on an immanent plane, thereby stripping it of its ontological privilege. Moreover, new materialists hold that all matter (including organic matter) has agential capacities. This idea is depicted in Barad's (2007:132) concept of 'agential realism'. Another important contention of new materialism is that ontology, epistemology, and ethics are inseparable, captured in Barad's (2007:409) neologism, 'ethico-ontoepistemology'. This means that the human is not a self-contained individual entity but is, instead, transformed by the interconnections it produces. The connections it produces cannot be known in advance and are immanently present in the human-human-nature-technology assemblage.

Speculative realism designates a range of thought produced by a community of philosophers. It concerns a return to speculating on the nature of reality independently of human thought and holds that continental philosophy (phenomenology, structuralism, post-structuralism, deconstruction, and postmodernism) has descended into an anti-realist stance in the form of what Meillassoux (2008:5) terms 'correlationism'. Put simply, correlationalism means that reality appears only as the correlate of human thought. In other words, we can access only that which is such a correlate. The limit of correlationalism is the reason why conventional continental philosophy might be considered to be anthropocentric. Furthermore, some speculative realists share a commitment to a flat ontology or object-oriented ontology (OOO), which holds that all entities are objects and that they should be treated equally by not prematurely reducing some to others (see Harman 2013; 2018; Morton 2018). A chair, a rock, a magnetic wave, a work of fiction, a giraffe, a flower, a seed, capitalism are all objects. According to Harman (2018) an object-oriented ontology jettisons the distinctions thought /world and human/ non-human. He goes on to argue that an object cannot be reduced to either one of the 'two basic kinds of knowledge: what something is made of, and what it does' (Harman 2018: 257). What this means is that an object can form unique relations with other objects and that such relations are independent of any predetermined qualities imposed by humans. In such relations it cannot be predetermined what an object will do or what it will become and, more importantly, objects forge relations with one another that transcend human thought and perception. As Snaza et al. (2014:47) write,

... OOO marks a renewed ethico-ecological commitment to geophilosophy ... while advancing the image of a new or ungrounded 
earth teeming with ecologies of relation prior to their presumed enlivenment by human thought (italics in original).

Non-representational theory was first developed by human geographer Nigel Thrift and colleagues and the genesis of these ideas is captured in several of his own works; see Thrift (1996; 1997; 1999; 2000; 2003; 2007). Nonrepresentation theory is not a single theory but denotes, rather, a disposition that calls into question the overemphasis on representations (products of the human mind) and instead places emphasis on performances and practices - the embodiment, materiality, and processes of performing geographical work. Non-representational theory has, of course, application beyond geography and also resonates with work in the sociology of knowledge performed by scholars such as David Turnbull (1997; 2000).

I argue that new materialism, speculative realism, and nonrepresentational theory are intellectual endeavours involved in developing "theories" ${ }^{7}$ in the (post)human condition. Each of the endeavours discussed does not represent a single 'theory' but a range of perspectives or strands of thought. However, what all (post)human 'theorists' have is common is their opposition to human exceptionalism. (Post)humanism questions the primacy of the human in the cybernetic triangle of human/animal/machine. In other words, the human does not enjoy ontological privilege and is placed on an immanent plane alongside all modes of life (or, for OOO scholars, all objects).

Rejecting human exceptionality entails opening politics to nonhuman subjects and, by implication, also to those who have been viewed as less than human by modern imperialist states (Wolfe 2012). The sphere of distributive justice becomes expanded from social justice to a multi-species ecojustice. Rejecting human exceptionalism also has implications for education and curriculum because much of Western education has been based on human exceptionalism. Snaza et al. (2014) aver that schooling in western(ised) societies has served to civilise us, to tame our wild animal impulses by privileging 'rational' thought in relation to our bodies, which is captured in Descartes's cogito ergo sum ('I think therefore I am'.) Human exceptionalism is evident in the hidden curriculum of western(ised) schools and universities

7 I place 'theories' in scare quotation marks because many (post)human scholars would reject the notion of theory and see new materialism, speculative realism, and non-representational theory as dispositions rather than theories. 
because we learn that we are unlike animals and we can do with them whatever we wish. As Snaza et al. (2014:45) cogently put it,

... in schools [and universities] ... we learn a whole set of humanist ideas about human exceptionalism (in biology, social studies, languages, etc.) while learning to ignore both the ways some humans are treated as 'more human' than others (which then justifies waging all sorts of horrors against other humans) and also the concrete ways that humans and other animals actually relate in schools: dissections in biology class, eating dead animals and the byproducts of their killing in cafeterias and hallways, wearing animals on our feet, tossing balls made of their skins in gym class.

Reconnecting humans to their animality would imply a radical reimagining of education. But Snaza et al. (2014) remind us more specifically of another challenge for education and curriculum. They point out that in educational thought correlationalism is manifest in the privileged place given to epistemology and portrayed in the perennial curriculum question, What knowledge is of most worth? And I would add even the more radical question, Whose knowledge is of most worth? This raises a new question about how we might think curriculum in the (post)human condition and how we might conceive of the field Curriculum Studies, which is concerned with understanding curriculum. Snaza et al. (2014) suggest that Curriculum Studies should return to its emphasis on democratic forms of being-together (or beingwith) in learning without reference to human exceptionalism. I shall return to some of these matters later in the article but turn now to a discussion of decolonisation and decoloniality.

\section{Decolonisation and Decoloniality}

In this article decolonisation ${ }^{8}$ refers to the undoing of colonisation. It began when colonised peoples fought and pushed back against colonial admini-

\footnotetext{
${ }^{8}$ Decolonisation continues to be used by indigenous peoples across the world to denote their struggle for self-determination, to correct the deficit ways in which they have been defined, to retell stories of their past, and to envision the future (see Smith 1999; Chilisa 2012).
} 


\section{Lesley le Grange}

strations until we witnessed the end of colonial rule. Ndlovu-Gatsheni (in Omanga 2020) argues that in Africa South of the Sahara decolonisation needs to be understood as phases beginning with primary resistance movements such as the Ndebele-Shona Uprisings in southern Africa (1896-1897) and the Maji Maji in east Africa (1905-1907), which formed the basis for future nationalistanticolonial struggles, exemplified by the Mau-Mau Uprisings (1952-1960). Most African countries obtained independence in the mid-twentieth century, with South Africa being the last African country to be decolonised in 1994, following decades of anti-apartheid struggles. Natsheni-Gatsheni (2013a) argues that apartheid was a form of internal white colonialism.

However, the end of colonisation did not mean the end of coloniality. Fanon (1967) understood this when he lamented at the end of the Algerian war that decolonisation did not take place, only the Africanisation of colonialism did. Nkrumah (1965) understood this, too, with his coinage of neo-colonialism. However, Latin American scholars have been particularly helpful in articulating what the legacy of colonialism is. They do so by distinguishing between colonisation/colonialism and coloniality and therefore between decolonisation and decoloniality. The Latin American scholars include Anibal Quijano, Nelson Maldonado-Torres, Ramón Grosfoguel, and Walter Mignolo. It was Quijano (2007) who gave new meaning to the term that depicts the legacy of colonialism. He argues that the legacy of colonialism is the colonial matrix of power that has four interlocking domains: control of economy (land appropriation, exploitation of labour, control of natural resources); control of authority (institutions, army); control of gender and sexuality (family, education) and control of subjectivity and knowledge (epistemology, education, and identity formation). Grosfoguel (2007) avers that the removal of colonial administrations produced the myth of a postcolonial world. He writes,

We continue to live under the same colonial power matrix. With juridical-political decolonisation we moved from a period of 'global colonialism' to the current period of 'global coloniality'.

Similarly, Maldonado-Torres (2007:243) points out that coloniality refers to,

long-standing patterns of power that emerged as a result of colonialism, but that define culture, labour, intersubjectivity relations, 
and knowledge production well beyond the strict limits of colonial administrations.

Moreover, Mignolo $(2007 ; 2011)$ argues that coloniality is the darker side of modernity. By this he means that there is no European modernity without coloniality. In other words, the darker side of modernity is the slave trade, imperialisms, violent genocides, racism, sexism, all forms of oppression suffered by colonised peoples, and the current neoliberal order. Some of the 'crimes' of the darker side of modernity are the murdering and displacement of pre-existing knowleges (epistemicide); the killing and displacement of the languages of colonised peoples (linguicide); and the killing and displacement of peoples' cultures (culturecide) (Ndlovu \& Omanga 2020). Drawing on the work of these Latin American scholars Ndlovu-Gatsheni (2013b) argues that coloniality has three interlocking concepts: coloniality of power; coloniality of knowledge; and coloniality of being. Coloniality of power relates to the current asymmetrical global power structure that is a consequence of the benefits of modernisation that has been enjoyed by the West through imposing the slave trade, imperialism, colonialism, and apartheid on the rest. Coloniality of knowledge relates to how the genesis of disciplines in the West resulted in epistemicides in the Global South and how Africa is now burdened with irrelevant knowledge that disempowers rather than empowers. Coloniality of being relates to how whiteness gained ontological density that far exceeds that of blackness and how Descartes's 'I think, therefore, I am' morphed into 'I conquer, therefore, I am' (Ndlovu-Gatsheni 2013a:12).

Decoloniality is an analytic of coloniality. It concerns a critical awareness of the logic of coloniality (the colonial matrix of power), it is a critique of coloniality, resists expressions of coloniality, and takes actions to overcome coloniality. In other words, decoloniality is more than the elimination of colonial administrations and entails the decolonisation of the interlocking domains of knowledge, power, and being. As Maldonado-Torres (2006:117) writes,

By decoloniality ... is meant ... the dismantling of relations of power and conceptions of knowledge that foment the reproduction of racial, gender, and geopolitical hierarchies that came into being or 
found new and more powerful forms of expression in the modern/colonial world.

In relation to Curriculum Studies Le Grange (2018:9) argues that decoloniality demands asking critical questions such as:

Who controls the field internationally and in South Africa? Who controls the institutions and organisations of the field? Who produces knowledge in and of the field (including its histories)? How are identities (per)formed or constructed through and in discourses on Curriculum Studies?

With respect to decolonising of the school and university curriculum, decoloniality petitions more than the dismantling of Western conceptions of knowledge to entail also dismantling the deficit ways in which colonised peoples have been defined, the correction of unequal power relations, and the undoing of the current idea of the contemporary school/university and its actualisation. Le Grange (2016) argues that the curriculum-as-lived by students and lecturers should be legitimated so that the concept curriculum is understood as broader than the explicit curriculum, so that attention is given to the hidden curriculum and the null curriculum.

\section{4 (Post)humanism and Decoloniality}

As mentioned, what (post)human theories all have in common is the rejection of human exceptionalism. This means that the human is stripped from its ontological privilege and placed on an immanent plane with all modes/objects of life. For (post)humanists the human is not an isolated individual but is entangled in an assemblage of living and 'non-living.' If assemblage is the unit of reference in the post-Anthropocene, then this raises a critical question of what 'human' now means. And for our discussion, also what this invites in relation to the concept curriculum and the field Curriculum Studies. Decoloniality seeks to disrupt the colonial matrix of power that is the legacy of European colonialism. It challenges the asymmetrical power relations between the Global North and Global South within nations and between and within institutions such as schools and universities. Moreover, it challenges the dominance of Western epistemic rationality and the deficit ways in which 
colonised peoples have come to be defined. Decoloniality thus demands the disruption of the dominant notion of curriculum and calls for the disruption of the field of Curriculum Studies.

(Post)humanism and decoloniality may have some things in common. Zembylas (2018) argues that both (post)human and decolonial perspectives challenge the individualistic, possessive, and competitive subjectivity that is constructed as ideal in the neoliberal university and therefore potentially opens up pathways for reimagining university curricula and pedagogies. This holds true for schools, too. Moreover, the two perspectives aim to remove from its pedestal the ideal human (white male) constructed by European enlightenment. However, de Oliveira and Lopes (2016) argue that (post)human and decolonial perspectives might have different priorities. (Post)humanism's rejection of human exceptionalism and belief in the entanglement of humans in assemblages of living and non-living may be viewed by decolonial scholars as further denial of the humanity of colonised and racialised peoples - a humanity denigrated by persistent coloniality of being. Or as Zembylas (2018:262) puts it,

decolonial scholarship exposes posthumanism as another false universal brought by the post-Enlightenment subject, offering an alibi for the sustained denial of the humanity of colonised and racialised peoples.

He goes on to ask a critical question: How does the pervasive idea of a 'morethan-human' perspective of post-humanism dismantle the hidden agendas of colonial practices at all levels of society (including the university) without returning to an idealized anthropocentric past? I shall attempt to respond to this question in the next section of this article by introducing the concept of ubuntucurrere as a portal to a reimagined notion of curriculum that could take us beyond the impasse of (post)human and decolonial scholarship. While the humanity of colonised and racialised bodies might be a blind spot of (post)humanism, it does foreground what might be neglected by decolonialists, which is a concern for the more/other-than-human and an acknowledgement of our imbrication with advanced technologies in a human-human-naturetechnology assemblage.

(Post)humanism and decoloniality provide languages for critiquing the contemporary Western university and school and its notion of curriculum - the 


\section{Lesley le Grange}

former for the privileging of knowledge and the latter for the privileging of Western knowledge, which has resulted in the denigration and well as decimation of the knowledges of colonised and racialised peoples. Both perspectives would therefore trouble the perennial curriculum question of what knowledge is of most worth, which was first used as the title of a book by Hebert Spencer (1884). (Post)humanists would suggest that this question might be the wrong one because it privileges knowledge above being and human action in the world and negates the imbrication of epistemology, ontology, and axiology as captured in Barad's (2007) ethico-onto-epistemology. (Post)humanists would also reject the perennial curriculum question because it implies that knowledge is only the product of human thought (with an emphasis on the individual) and that human thought transcends human embeddedness in the web of life. Decolonial scholars might agree in part with (post)humanists but would ask a different question: Whose knowledge is of most worth? This question draws attention to the killing and marginalisation of the knowledges of colonised and racialised peoples.

However, although (post)humanist and decolonial perspectives are useful analytics of the Western(ised) school and university and its curriculum, these perspectives offer little insight into how to imagine or disrupt this curriculum. It is with this mind that I introduce ubuntu-currere as a concept that might open possibilities for imagining the different curriculum that enables (post)human and decolonial perspectives to meet each other halfway. This is because ubuntu-currere captures at least some dimensions of both (post)human and decolonial perspectives.

\section{Ubuntu-currere: Towards a (Post)human-decolonial Curriculum}

Ubuntu-currere is an amalgam of the African notion of ubuntu and a conception of curriculum that draws on the Latin origin of curriculum which means 'to run.' Ubuntu/ Botho is a concept that is derived from proverbial expressions (aphorisms) found in several languages in Africa south of the Sahara. It is not only a linguistic concept but has a normative connotation embodying how we ought to relate to the other or, in other words, what our moral obligation is towards the others. Ubuntu derives from the aphorism umuntu ngumuntu ngabantu which cannot be translated easily but generally means that each individual's humanity is expressed in relationship with others. 
Metz (2007) argues that this aphorism not only describes the way African people relate to one another but also the way in which they ought to relate to one another. Therefore, ubuntu means that our deepest moral obligation is to become more fully human and, if one is to achieve this, it requires one to enter more deeply into community with others. However, ubuntu should not be equated with humanism. As Ramose (2009, pp. 308-309) writes,

Humanness suggests both a condition of being and the state of becoming, of openness or ceaseless unfolding. It is thus opposed to any '-ism', including humanism, for this tends to suggest a condition of finality, a closedness or a kind of absolute either incapable of, or resistant to, any further movement.

Moreover, Le Grange (2012) argues that ubuntu needs to be understood as a microcosm of the Shona construct ukama, which means relatedness of all things in the cosmos. Drawing on the work of Guattari (2001), he points out that the interrelatedness of the three ecological registers, the self, social, and ecology ('nature'), needs to be understood transversally; destruction in one register will be witnessed in the other two and so, too, healing in one of the registers would be witnessed in the other two. A human who authentically cares for another human being would also care for the self and for the more/otherthan-human world.

There are four insights that might be gained from the discussion on ubuntu and ukama. First, the human-human-nature connection depicted in ubuntu-ukama resonates strongly with the (post)human perspectives described in this article. In other words, ontological privilege is not ascribed to the human. Second, the oneness of all of life captured by (post)humanism and ukama does not deny the ethico-normative distinctiveness of the species Homo Sapiens. Therefore, through affects unique to its species, humans can express attributes of love, hate, caring, joy, (com)passion, and so forth. Third the ethico-normative distinctiveness of the human, which ubuntu embodies, means that social justice need not be sacrificed at the altar of multispecies ecojustice. Fourth, the moral obligation implied in the aphorism from which ubuntu is derived, petitions humans to care for both humans and the more/other-than human world. Harming other humans and non-human nature would therefore be counter to ubuntu. This includes all forms of discrimination, which resonates with the decolonial critique of the coloniality of being. 
Currere is the second concept of the amalgam ubuntu-currere. Fortyfive years ago, Pinar (1975) first invoked the etymological root of curriculum, the Latin currere, which means 'to run the course.' He did so to refocus curriculum on the significance of individual experience irrespective of the course content or alignment with society or the economy (Pinar 2011). Wallin (2010) revisited the notion of currere by thinking with Deleuze and Guattari (1994) and their assertion that a concept is not a name attached to something but a way of approaching the world. Deleuze and Guattari's (1994) interest was not in what a concept is but what it does or what it could become. In other words, what it wills to power. Wallin (2010) draws attention to the paradoxical character of currere's etymology given its active and reactive forces. He suggests that curriculum could be thought of as an active conceptual force which means that it does not have fixity or closedness; it does not convey an $a$ priori image of a pedagogical life. Instead, it relates to the immanent potential of the becoming of a pedagogical life, the multiple coursings of a pedagogical life that exists prior to thought. The active force of currere relates to the creative power within all of life including human beings. It is the same power that enables objects (as understood in OOO) to create flows, to connect, and to expand difference. The active force of currere resonates strongly with ubuntu in its concern with the unfolding of the human being in relationship with other humans and the more/other-than-human world.

The conceptual power of currere implies newness, creation of things unforeseen, experimentation, expanding of difference, and movement. This notion of curriculum opens up multiple pathways for the becoming of pedagogical lives and therefore the basis for decolonisation. The active force of currere is decolonising in that it opens up (not closes) what a body (a concept, a person, an organisation etc.) can do/become. Through its movement currere creates new connections, new assemblages, and unlikely fidelities. Currere signifies a life of experimentation through the release of immanent flows rather than constructing transcendent ideas that are imposed. In other words, the becoming of the person is constrained only by life itself; freedom is constrained only when human actions harm other humans or the more/otherthan-human world. Here the alignment with ubuntu-ukama and the different (post)human perspectives discussed in the article is evident. In its reactive form, currere colonises, where one way of knowing becomes the way of knowing. The reactive power of currere severs curriculum from its immanent potential to become other. It is currere's reactive force that has dominated 
conceptions and practices of curriculum in Western(ised) schools and universities as evidenced by the normalising and homogenising effects of various iterations of the Tylerian rationale such as competency-based education, outcomes-based education, and constructive alignment (Gough 2013).

Ubuntu-currere shifts the register of reference away from the individual human being to an assemblage of human-human-nature-technology. In other words, subjectivity is ecological. This resonates with what all (post)humanist perspectives have in common, which is the rejection of human exceptionalism and acceptance of the assemblage as unit of reference. The assemblage is comprised of objects (as in the OOO of speculative realism), which all have agential capacities (as in new materialist thought) and the human is one such object. This does not mean that the ethico-normative distinctiveness of the animal species we call human to express love, joy, caring, compassion, anger and to seek justice (cognitive, social, linguistic), etc., is denied. This makes possible the invigoration of lines of connection between ubuntu-currere and decolonialility. Moreover, ubuntu-currere embodies the idea of the subject as always in becoming and that the becoming of a pedagogical life is relational - the subject becomes in relation to other humans and the more-than-human-world. The notion of in-becoming ensures that the human cannot be defined nor have fixity and therefore ubuntu-currere is (post)humanist/anti-humanist. The concept embraces the right to live and thrive, free from any force that imposes, except the constraint of life itself, and therefore resonates with decoloniality. Ubuntu-currere has resonance with new materialist post-human theory in that it embraces an ontology of immanence that there is a material immanent plane that connects everything in the cosmos and from which all actualised forms unfold/become. As Le Grange (2019b:223) writes,

Ubuntu-currere opens up multiple coursings for developing posthuman sensibilities driven by the positive power of potentia that connects, expresses desire and sustains life .... But it also makes possible conversations with the more-than-human so that we can listen to the rhythm and heartbeat of the earth so that our conversations do not happen on the earth but are bent by the earth. 


\section{Lesley le Grange}

Ubuntu-currere is an educative performance where there is no a priori image of a life and where there are no predetermined outcomes, goals, aims, etc. In such an educative performance, objects (as in OOO) such as books, classrooms/lecture venues, a national curriculum framework, etc. do not represent what curriculum is nor what a body could become; the becoming of a pedagogical life occurs in intra-action with objects such as the ones mentioned and objects in the more/other-than-human-world. Ubuntu-currere therefore aligns with non-representational theory.

\section{Parting Thoughts}

Ubuntu-currere disrupts dominant notions of curriculum that predetermine a pathway for pedagogical lives, akin to the Grecian notion of currere which means 'chariot track' - the course to run. It calls for a life of experimentation through engaging with all the complex challenges facing Planet Earth: growing inequality; environmental destruction; violence of all kinds; the benefits and treats of advanced technologies; global health pandemics; and so forth. Ubuntu-currere petitions an ethic of just doing (just acting) in whatever way that will enhance life (both human and non-human) and learning with such doing/acting.

For Curriculum Studies, ubuntu-currere calls on scholars of the field to listen respectfully to others in the transnational spaces that globalisation affords, akin to Pinar's (2004) notion of curriculum as complicated conversation. Pinar (2004) averred that complicated conversations require frank and ongoing self-criticism when listening to others. Le Grange (2018:7) elaborates,

Frank and ongoing self-criticism is an important dimension of complicated conversations because it mitigates against hierarchical power relations that could impede productive conversations from happening. Power relations are always present when humans engage in educational exchanges. However, complicated conversations are constructed to lessen hierarchical power relations and their colonising effects. When this potestas (negative power) is moderated through self-criticism and respect, the positive power of the potentia can flourish and productive curriculum work can be performed in new knowledge spaces. Potentia is not a power that is external, 
hierarchical, or imposed, but is an immanent power that connects to life's creative force ....

And for the (post)humanist and many indigenous peoples, our conversations are never purely human ones because our thoughts and being are always already embedded in the web of life. I do not wish to conclude by putting what I have said in a nutshell for the reader, but, instead, invite ongoing complicated conversations on (post)humanism, decoloniality, and curriculum.

\section{References}

Barad, K. 2007. Meeting the Universe Halfway: Quantum Physics and the Entanglement of Matter and Meaning. Durham, NC: Duke University Press. https://doi.org/10.1215/9780822388128

PMCid:PMC1450142

Braidotti, R. 2012. Afterword: Complexity, Materialism, Difference. Angelaki

17: 169-176. https://doi.org/10.1080/0969725X.2012.701056

Braidotti, R. 2013. The Posthuman. Malden, MA: The Polity Press.

Bowles, S. \& H. Gintis. 1976. Schooling in Capitalist America: Educational

Reform and the Contradictions of Economic Life. New York: Basic Books.

Chilisa, B. 2012. Indigenous Research Methodologies. Los Angeles, CA: Sage. Christie, P. 2020. Decolonising Schools in South Africa: The Impossible Dream? London and New York: Routledge.

https://doi.org/10.4324/9780367853624

Council on Higher Education (CHE). 2020. VitalStats: Public Higher Education 2018. Pretoria: CHE.

Crutzen, P. \& E. Stoermer. 2000. The Anthropocene. Global Change Newsletter 41, 1: 17-18.

Deever, B. 1996. If Not Now, When? Radical Theory and Systematic Curriculum Reform. Journal of Curriculum Studies 28, 2: 171-191.

https://doi.org/10.1080/0022027980280204

Deleuze, G. \& F. Guattari. 1994. What is Philosophy? H. Tomlinson \& G. Burchell (trans.). New York, NY: Columbia University Press.

De Oliveira, T.R.M. \& D.B Lopes. 2016. On the Limits of the Human in the

Curriculum Field. Curriculum Inquiry 46, 1: 110-125.

https://doi.org/10.1080/03626784.2015.1113512 
Du Preez, P. 2018. On Decolonisation and Internationalisation of University Curricula: What Can we Learn from Rosi Braidotti? Journal of Education 74: 19-31. https://doi.org/10.17159/2520-9868/i74a02

Du Preez, P. \& L. Le Grange. 2020. The COVID-19 Pandemic, Online Teaching/learning, the Digital Divide and Epistemological access. In Ramrathan, L., J.A. Smit, N. Hlongwe, N. Mkhize (eds.): Re-thinking the Humanities Curriculum within the Time of COVID-19. (Alternation African Scholarship Book Series, Volume 1). Pietermaritzburg: CSSALL Publishers.

Fanon, F. 1967. Towards the African Revolution. H. Chevalier. (trans.). New York, NY: Grove Press.

Giroux, H.A. 1988. Schooling and the Struggle for Public Life. Minneapolis:

University of Minnesota.

Gough, N. 2013. Towards a Deconstructivist Nonalignment: A Complexivist

View of Curriculum, Teaching and Learning. South African Journal of Higher Education 27, 5: 1213-1233.

Grosfoguel, R. 2007. The Epistemic Decolonial Turn. Cultural Studies 21, 2/3: 211-223. https://doi.org/10.1080/09502380601162514

Grosfoguel, R. 2011. Decolonizing Post-Colonial Studies and Paradigms of Political-Economy: Transmodernity, Decolonial Thinking, and Global Coloniality. Transmodernity: Journal of Peripheral Cultural Production of the Luso-Hispanic World 1, 1: 1-37.

Guattari, F. 2001. The Three Ecologies. I. Pindar \& P. Patton. (trans.). London: The Athlone Press.

Haraway, D. 1985. Manifesto for Cyborgs: Science, Technology and Social Feminism in the 1980s. Socialist Review 80: 65-108.

https://doi.org/10.1215/22011919-3615934

Haraway, D. 2006. A Cyborg Manifesto: Science, Technology, and Socialistfeminism in the late $20^{\text {th }}$ Century. In Weiss, J., J. Nolan, J. Hunsinger, \& P. Trifonas (eds.): The International Handbook of Virtual Learning Environments. Dordrecht: Springer.

Haraway, D. 2015. Anthropocene, Capitalocene, Plantationocene, Chthulucene: Making Kin. Environmental Humanities 6: 159-165.

Harman, G. 2013. Tristan Garcia and the Thing-in-itself. Parrhesia 16: 26-34. Harman, G. 2018. Object-oriented Ontology: A New Theory of Everything. London: Penguin Random House. https://doi.org/10.1093/acrefore/9780190201098.013.997 
Hodges, C., S. Moore, B. Lockee, T. Trust, \& M. Bond. 2020. The Difference between Emergency Remote Teaching and Online Learning. Available at: https://er.educause.edu/articles/2020/3/the-difference-betweenemergency-remote-teaching-and-online-learning (Accessed on 24 April 2020).

Le Grange L. 2012. Ubuntu, Ukama and the Healing of Nature, Self and Society. Educational Philosophy and Theory 44, S2 (Special issue on Africa, September): 56-57.

https://doi.org/10.1111/j.1469-5812.2011.00795.x

Le Grange, L. 2016. Decolonising the University Curriculum. South African Journal of Higher Education 30, 2: 1-12. http://dx.doi.org/10.20853/302-709. https://doi.org/10.20853/30-2-709

Le Grange, L. 2018. Decolonising, Africanising, Indigenising and Internationalising of Curriculum Studies: Opportunities to (Re)imagine the Field. Journal of Education 74: 5-18.

https://doi.org/10.17159/2520-9868/i74a01

Le Grange, L. 2019a. The Anthropocene: Becoming-imperceptible of (Environmental) Education. On Education. Journal for Research and Debate 2, 4: 1-6. https://doi.org/10.17899/on_ed.2019.4.4

Le Grange, L. 2019b. Currere's Active Force and the Concept of Ubuntu. In Hébert, C., N. Ng-A-Fook, A. Ibrahim, \& B. Smith (eds.): Internationalizing Curriculum Studies: Histories, Environments, and Critiques. New York: Palgrave MacMillan. https://doi.org/10.1007/978-3-030-01352-3_13

Le Grange, L. 2020. Could the COVID-19 Pandemic Accelerate the Uberfication of the University? South African Journal of Higher Education 34, 4: 1-10.

https://doi.org/10.20853/34-4-4071

Le Grange, L., C. Reddy, \& P. Beets. 2012. Socially Critical Education for a Sustainable Stellenbosch by 2030. In Swilling, M., B. Sebitosi \& R. Loots (eds.): Sustainable Stellenbosch: Opening Dialogues. Stellenbosch: African Sun Media Publishers.

Levinas E. 1987. Humanism and An-archy. In Collected Philosophical Papers. Phaenomenologica (Collection Fondée par H.L. van Breda et Publiée sous le Patronage des Centres d'Archives-Husserl), vol 100. Dordrecht: Springer 
Maldonado-Torres, N. 2006. Cesaire's Gift and the Decolonial Turn. Radical Philosophy Review 9, 2: 111-138.

https://doi.org/10.5840/radphilrev20069217

Maldonado-Torres, N. 2007. On Coloniality of Being: Contributions to the Development of a Concept. Cultural Studies 21, 2/3: 240-270. https://doi.org/10.1080/09502380601162548

McKinley, D. 2020. Coronavirus and Capitalism: Structural Foundations and Opportunities for Systemic Change. Daily Maverick. Available at:

https://www.dailymaverick.co.za/opinionista/2020-03-24 trashed-2/

(Accessed on 5 June 2020.)

Meillassoux, Q. 2008. After Finitude: An Essay on the Necessity of Contingency. Brassier, R. (trans.). New York: Continuum.

Metz, T. 2007. Toward an African Moral Theory. Journal of Political Philosophy 15, 3: 321-341. https://doi.org/10.1111/j.14679760.2007.00280.x

Mignolo, W.D. 2007. Delinking. Cultural Studies 21, 2/3: 449-514. https://doi.org/10.1080/09502380601162647

Mignolo, W.D. 2011. The Darker Side of Western Modernity: Global Futures, Decolonial Options. Durrham and London: Duke University Press. https://doi.org/10.1515/9780822394501

Morton, T. 2013. Hyperobjects: Philosophy and Ecology after the End of the World. Minneapolis, MN: The University of Minnesota Press.

Morton, T. 2018. Being Ecological. London: Penguin Random House. https://doi.org/10.7551/mitpress/11638.001.0001

Murris, K. 2016. \#RhodesMustFall: A Posthumanist Orientation to Decolonising Higher Education. South African Journal of Higher Education 30, 3: 274 -294. https://doi.org/10.20853/30-3-653

Ndlovu-Gatsheni, S. J. 2013a. Why Decoloniality in the 21 st century? The Thinker 48: 10-15.

Ndlovu-Gatsheni, S.J. 2013b. Empire, Global Coloniality and African Subjectivity. New York: Berghahn Books.

Ndlovu-Gatsheni, S.G. \& D. Omanga. 2020. Decolonisation, Decoloniality and the Future of African Studies. Available at: https://oxfamblogs.org/fp2p/decolonization-decoloniality-and-thefuture-of-african-studies/ (Accessed on 25 July 2020).

Nkrumah, K. 1965. Neo-colonialism: The Last Stage of Imperialism. London, UK: Nelson. 
Omanga, D. 2020. Decolonization, Decoloniality, and the Future of African Studies: A Conversation with Dr. Sabelo Ndlovu-Gatsheni. Available at: https://items.ssrc.org/from-our-programs/decolonization-decolonialityand-the-future-of-african-studies-a-conversation-with-dr-sabelo-ndlovugatsheni/ (Accessed on 10 June 2020).

Orr, D.W. 1992. Ecological Literacy: Education and the Transition to a Postmodern World. Albany, NY: State University of New York Press.

Pinar, W.F. 1975. The Method of Currere. Paper presented at the annual meeting of the American Educational Research Association. Washington, D.C.

Pinar, W.F. 2004. What is Curriculum Theory? Mahwah, NJ: Lawrence Erlbaum Associates.

Pinar, W.F. 2011. The Character of Curriculum Studies: Bildung, Currere, and the Recurring Question of the Subject. New York: Palgrave Macmillan. https://doi.org/10.1057/9781137015839_9

Postma, D. 2016. The Ethics of Becoming in a Pedagogy for Social Justice: A (Post)humanist Perspective. South African Journal of Higher Education 30, 3: 310-328. https://doi.org/10.20853/30-3-651

Ramose, M.B. 2009. Ecology through Ubuntu. In Murove, M.F. (ed.): African Ethics: An Anthology of Comparative and Applied Ethics. Pietermaritzburg: University of KwaZulu-Natal Press.

Quijano, A. 2007. Coloniality and Modernity/ Rationality. Cultural Studies 21, 2/3: 168-178. https://doi.org/10.1080/09502380601164353

Smith, L. 1999. Decolonising Methodologies: Research and Indigenous Peoples. London, UK: Zed Books.

Snaza, N., P. Appelbaum, S. Bayne, D. Carlson, M. Morris, N. Rotas, J. Sandlin, J. Wallin \& J. Weaver. 2014. Toward a Posthumanist Education. Journal of Curriculum Theorising 30, 4: 39-55.

Spencer, H. 1884. What Knowledge is of Most Worth? Michigan: University of Michigan.

Thrift, N. 1996 Spatial Formations. Sage, London.

Thrift, N. 1997. The Still Point. In Pile, S. \& M. Keith (eds.): Geographies of Resistance. Routledge, London.

Thrift, N. 1999. Steps to an Ecology of Place. In Massey, D., J. Allen and P. Sarre (eds.): Human Geography Today. Polity, Cambridge.

Thrift, N. 2000. Afterwords. Environment and Planning D: Society and Space 18, 213-255. https://doi.org/10.1068/d214t 
Thrift, N. 2003. Performance and... Environment and Planning A 35: 20192024. https://doi.org/10.1068/a3543a

Thrift, N. 2007. Non-Representational Theory: Space, Politics, Affect. Routledge, London. https://doi.org/10.4324/9780203946565

PMCid:PMC3359095

Turnbull, D. 1997. Reframing Science and Other Local Knowledge Traditions. Futures 29, 6: 551-562. https://doi.org/10.1016/S0016-3287(97)00030-X

Turnbull, D. 2000. Masons, Tricksters and Cartographers: Comparative Studies in the Sociology of Scientific and Indigenous Knowledge. London and New York: Routledge.

Wallin, J. J. 2010. A Deleuzian Approach to Curriculum: Essays on a Pedagogical Life. New York: Palgrave Macmillan.

https://doi.org/10.1057/9780230115286

Wolfe, C. 2012. Before the Law: Humans and other Animals in a Biopolitical Frame. Chicago, IL: University of Chicago Press.

https://doi.org/10.7208/chicago/9780226922423.001.0001

Zembylas, M. 2018. The Entanglement of Decolonial and Posthuman Perspectives: Tensions and Implications for Curriculum and Pedagogy in Higher Education. Parallax 24, 3: 254-267.

https://doi.org/10.1080/13534645.2018.1496577

Lesley Le Grange Distinguished Professor Department of Curriculum Studies Stellenbosch University Stellenbosch Email: 1lg@sun.ac.za 